\title{
Pd/C Catalyst with High Activity for Methanol Electrooxidation
}

\author{
Liquan Lu ${ }^{1, *}$, Jing Wang $^{1}$, Lafeng Guo ${ }^{1}$, Xi Zhao ${ }^{1}$, Yubin Zhang ${ }^{2}$, Yingjia Yang ${ }^{2}$, Shaohui Yan ${ }^{2, *}$ \\ ${ }^{1}$ College of Mechatronic Engineering, North University of China, Taiyuan 030051, China \\ ${ }^{2}$ College of Environmental Science and Engineering, Taiyuan University of Technology, Taiyuan, \\ 030024, China \\ *E-mail: lq_1u@buaa.edu.cn, shyan@buaa.edu.cn
}

doi: $10.20964 / 2019.07 .21$

Received: 7 March 2019 / Accepted: 18 April 2019 / Published: 10 June 2019

The $\mathrm{Pd} / \mathrm{C}$ catalysts (carbon supported Pd nanoparticles) were synthesized using a polyol process by quickly heating using microwave. The research results revealed that the Pd nanoparticles with small size were successfully deposited on the carbon support. Moreover, the surfaces of the Pd nanoparticles contain abundant (100) planes, which was of benefit to the improvement of their electrochemical activity. Furthermore, the actually Pd loadings for all the $\mathrm{Pd} / \mathrm{C}$ catalysts were closed to the theoretical loading (20 wt\%), indicating the high efficiency of this preparation method for the Pd nanoparticles depositing on the carbon. The transmission electron microscope and electrochemical test results indicated that the average diameter and the dispersity of the $\mathrm{Pd}$ nanoparticles in the $\mathrm{Pd} / \mathrm{C}$ catalysts, as well as the electrochemical activity of the $\mathrm{Pd} / \mathrm{C}$ catalysts were becoming firstly better, and then worse with the amount of the adding $\mathrm{KOH}$ solution, suggesting the mean size and dispersity of the Pd nanoparticles in the $\mathrm{Pd} / \mathrm{C}$ catalyst were the key factors affecting its electrochemical activity. The highest anodic massspecific current densities of the $\mathrm{Pd} / \mathrm{C}$ catalyst for the methanol electrooxidation in the $0.1 \mathrm{M} \mathrm{KOH}$ solution with $1 \mathrm{M} \mathrm{CH}_{3} \mathrm{OH}$ reached to $655.2 \mathrm{~mA} \mathrm{mg}^{-1} \mathrm{Pd}$, showing that the microwave-assisted polyol process was a suitable method for synthesizing the $\mathrm{Pd} / \mathrm{C}$ catalyst with good activity.

Keywords: Pd nanoparticles; Methanol electrooxidation; Microwave-assisted polyol process; Direct methanol fuel cells; Electrocatalysis

\section{$\underline{\text { FULL TEXT }}$}

(C) 2019 The Authors. Published by ESG (www.electrochemsci.org). This article is an open access article distributed under the terms and conditions of the Creative Commons Attribution license (http://creativecommons.org/licenses/by/4.0/). 